Research Paper

\title{
Elevated Creatinine Clearance in Lupus Nephritis patients with Normal Creatinine
}

\author{
Sheng Wang, Msc\#; Fang Wang, Msc\#; Xiao Wang, MD; Yuxian Zhang, Msc; Lijun Song, MD ${ }^{\bowtie}$ \\ Department of Rheumatology, Qilu Hospital of Shandong University, Ji'nan 250012, Shandong, China. \\ \#These authors contributed equally to this work. \\ $\triangle$ Corresponding author: Lijun Song, Department of Rheumatology, Qilu Hospital of Shandong University; No. 107 Wenhua Xi Road, Ji'nan 250012, China. \\ E-mail: 200462000958@sdu.edu.cn. \\ (C) The author(s). This is an open access article distributed under the terms of the Creative Commons Attribution License (https://creativecommons.org/licenses/by/4.0/). \\ See http://ivyspring.com/terms for full terms and conditions.
}

Received: 2020.07.26; Accepted: 2021.01.07; Published: 2021.01.29

\begin{abstract}
Objectives: The present study aimed to observe the differences in creatinine clearance (Ccr) in systemic lupus erythematosus (SLE) patients with normal serum creatinine at different levels of urinary protein.

Method: The present cross-sectional study included 177 SLE patients with normal serum creatinine from Qilu Hospital of Shandong University between January 2010 and April 2020. The following data were collected: blood urea nitrogen (BUN), serum creatinine (Cr), serum total protein, serum albumin, immunoglobulin (lg) $\mathrm{G}$, IgA, IgM, complement 3, complement 4, anti-ds-DNA antibody, routine urine test, urine protein/creatinine ratio (UPCR) $(\mathrm{g} / \mathrm{g})$, and the SLE disease activity index. The estimated $\mathrm{Ccr}$ was calculated according to the Cockcroft formula.

Results: 123 patients were with positive urinary protein (Lupus Nephritis, LN group) and 54 patients were with negative urinary protein (Non-LN group). Compared with the Non-LN group, the LN group had higher $\mathrm{BUN}(5.76 \pm 3.22$ vs. $4.78 \pm 1.58, \mathrm{P}=0.007)$ and $\mathrm{Cr}(62.36 \pm 19.53$ vs. $54.83 \pm 11.09, \mathrm{P}=0.001)$. There was a strong correlation between the UPCR and the semi-quantitative determination of urine protein in LN patients $(r=0.9583, P=0.0417)$. The serum creatinine levels were significantly higher in patients with urine protein $3+$ $(72.97 \pm 25.16)$ or massive proteinuria $(62.32 \pm 19.66)$ than the other groups. Patients with urinary protein \pm exhibited a significantly elevated $\mathrm{Ccr}$ when compared to patients with urinary protein $3+(130.6 \pm 44.15$ vs. 110.5 $\pm 33.50, P=0.02$ ), and patients with UPCR $<0.15 \mathrm{~g} / \mathrm{g}$ had higher $\mathrm{Ccr}$ than other groups and showed significantly increased Cor compared with patients with UPCR $\geq 0.15 \mathrm{~g} / \mathrm{g}$ (132.44 \pm 21.02 vs. 115.14 \pm 35.89 , $\mathrm{P}=0.007)$.

Conclusions: Early renal function impairment may be present in $L N$ patients. The kidneys of $L N$ patients with urinary protein \pm or UPCR $<0.15 \mathrm{~g} / \mathrm{g}$ are in a state of hyperfunction.
\end{abstract}

Key words: lupus nephritis; creatinine; creatinine clearance; protein urine; urine protein/creatinine ratio

\section{Introduction}

Systemic lupus erythematosus (SLE) is an autoimmune disease that involves multiple body systems and multiple autoantibodies. Renal involvement is one of the most common and serious manifestations of SLE [1]. Despite the improvement in its treatment, there is still an increase in mortality for people with SLE, when compared to matched controls $[2,3]$.

It has long been hoped that certain clinical manifestations could predict the pathological damage to the kidney without the need for renal biopsy, thereby enabling the early diagnosis and selection of appropriate treatment options. However, according to previous research, no consistent clinical-pathological relationship can predict the patterns or severity of histological findings based on clinical renal manifestations $[4,5]$.

The assessment of the glomerular filtration rate (GFR) is essential in clinical practice [6]. In recent years, several new equations have been developed to estimate the GFR, such as the Modification of Diet in Renal Disease (MDRD) equation [7], the Schwartz equation [8], and the Chronic Kidney Disease Epidemiology Collaboration (CKD-EPI) equation [9]. 
Although the National Kidney Foundation (NKF) suggests the use of these equations to estimate GFR, rheumatologists continue to use creatinine clearance (Ccr) [10]. In fact, the Cockcroft-Gault (CG) equation [11] is still widely adopted for the estimation of creatinine clearance in rheumatic clinical practice due to its superior convenience.

The application value of Ccr in lupus nephritis (LN) patients with elevated serum creatinine and the accuracy of various formulas have been widely verified $[10,12,13]$, but the value of the Ccr in LN patients with normal serum creatinine has been overlooked. As we know, diabetic nephropathy patients in the early stages of the disease will show an increased GFR [14]. Whether LN patients with normal serum creatinine exhibit a similar change in the early stages of the disease as those with diabetic nephropathy remains unclear. In the present study, the investigators aimed to clarify the difference in Ccr based on various urinary protein levels, and the relationship between Ccr and urinary protein level, as well as other clinical and laboratory tests in SLE patients with normal serum creatinine.

\section{Methods}

\section{Study Population}

The present study is a cross-sectional study that included 177 SLE patients with normal serum creatinine from Qilu Hospital of Shandong University between January 2010 and April 2020. SLE was diagnosed according to the 1997 American College of Rheumatology (ACR) criteria [15]. SLE patients with other autoimmune diseases, active infections, malignancies, and pregnant women were not included in the study. The present study was approved by the Medical Ethics Committees of Qilu Hospital of Shandong University and had been performed following the principles of the Declaration of Helsinki.

\section{Data Collection}

The following data were collected: age, gender, blood urea nitrogen (BUN), serum creatinine $(\mathrm{Cr})$, serum total protein (TP), serum albumin (Alb), immunoglobulin (Ig) G, IgA, IgM, complement $3\left(\mathrm{C}_{3}\right)$, complement $4\left(\mathrm{C}_{4}\right)$, and anti-ds-DNA antibody (ds-DNA). In addition, a routine blood test was performed, which included white blood cells (WBC), red blood cells (RBC), hemoglobin (HGB) and platelets (PLT). Based on the results of the routine urinary test, the urine protein was assigned one of six levels: -, $\pm 1+, 2+, 3+$ and 4+. Accordingly, SLE patients were defined as Non-LN (-) and LN $( \pm, 1+$, $2+, 3+$ and $4+)$, respectively. The urine protein/ creatinine ratio (UPCR) (g/g) was also collected. For the LN group, we classified all participants as having normal range proteinuria (UPCR $<0.15 \mathrm{~g} / \mathrm{g}$ ), mild proteinuria $(0.15 \leq \mathrm{UPCR}<0.5 \mathrm{~g} / \mathrm{g}), \quad$ moderate proteinuria $(0.5 \leq \mathrm{UPCR}<3.5 \mathrm{~g} / \mathrm{g})$, and massive proteinuria (UPCR $\geq 3.5 \mathrm{~g} / \mathrm{g}$ ) based on UPCR results. SLE disease activity was evaluated with SLEDAI-2K [16]. The estimated Ccr was calculated according to the following formula: $\mathrm{Ccr}=(140$-age [years] $) \times \mathrm{BW}$ $(\mathrm{kg}) / 72 \times \mathrm{Pcr} \times 0.011 \times$ correctional factor $\times$ (1.73/TBSA) Females: correctional factor (0.85) [11].

\section{Statistical Analysis}

SPSS 20.0 for Windows (SPSS Inc., Chicago, Illinois, USA) was used for all the analyses. All data were analyzed using a homogeneity test and presented as mean \pm standard deviation (SD) or median (range) unless otherwise stated. Independent-samples t-test or Mann-Whitney $U$ test was used for comparing the variables between the LN group and Non-LN group. The statistical analysis among multiple groups was performed with one-way ANOVA and post-hoc multiple comparisons by Bonferroni. The correlations between variables were assessed by Pearson's or Spearman's rank correlation coefficient. The nominal $P$-value used to determine statistical significance was $P<0.05$.

\section{Results}

\section{Demographic and laboratory characteristics in LN and non-LN patients}

54 patients were in the Non-LN group and 123 patients were in the LN group. The demographic characteristics and laboratory measurements are shown in Table 1. Compared with Non-LN patients, LN patients had higher BUN ( $\mathrm{P}=0.007), \mathrm{Cr}(\mathrm{P}=0.001)$ and anti-dsDNA antibody $(\mathrm{P}<0.001)$, and lower TP $(\mathrm{P}<0.001), \mathrm{Alb}(\mathrm{P}<0.001)$ and $\mathrm{C}_{4}(\mathrm{P}=0.023)$. There were no significant differences in complete blood count, including WBC, RBC, HGB and PLT, between Non-LN and LN patients. There was also no significant difference in the disease activity index (SLEDAI) between the two groups. Because most patients with urinary protein $4+$ presented with elevated serum creatinine, they were not included in this study.

\section{The comparisons of urine protein/creatinine ratio (UPCR) based on the semi-quantitative determination of urinary protein}

As shown in Figure 1A, the UPCRs were higher in patients with urinary protein $2+(2.114 \pm 1.666)$ and $3+(5.904 \pm 4.642)$ than in patients with urinary protein - $(0.247 \pm 0.348)$ and $\pm(0.214 \pm 0.201)$. Meanwhile, the UPCR was higher in patients with urinary protein $3+$ $(5.112 \pm 2.444)$ than in patients with urinary protein $1+$ 
$(1.108 \pm 1.538)$ and $2+(2.114 \pm 1.666)$. There was a strong correlation between the UPCR and semi-quantitative determination of urine protein in $\mathrm{LN}$ patients $(\mathrm{r}=0.9583, \mathrm{P}=0.0417$; Figure $1 \mathrm{~B})$.

Table 1. Demographic and laboratory characteristics in $L N$ and Non-LN patients

\begin{tabular}{lll}
\hline & Non-LN $(\mathrm{n}=54)$ & $\mathrm{LN}(\mathrm{n}=123)$ \\
\hline Age (years) & $37.13 \pm 13.43$ & $36.91 \pm 13.27$ \\
Male, $\mathrm{n}(\%)$ & $4(7.41 \%)$ & $21(17.1 \%)$ \\
WBC $\left(\times 10^{9} / \mathrm{L}\right)$ & $5.86 \pm 2.15$ & $6.74 \pm 4.16$ \\
$\mathrm{RBC}\left(\times 10^{12} / \mathrm{L}\right)$ & $3.87 \pm 0.54$ & $3.99 \pm 0.72$ \\
$\mathrm{HGB}(\mathrm{g} / \mathrm{L})$ & $113.41 \pm 15.18$ & $114.95 \pm 21.77$ \\
$\mathrm{PLT}\left(\times 10^{9} / \mathrm{L}\right)$ & $189.91 \pm 100.19$ & $205.08 \pm 95.66$ \\
$\mathrm{BUN}(\mathrm{mmol} / \mathrm{L})$ & $4.78 \pm 1.58$ & $5.76 \pm 3.22^{*}$ \\
$\mathrm{Cr}(\mathrm{umol} / \mathrm{L})$ & $54.83 \pm 11.09$ & $62.36 \pm 19.53^{*}$ \\
$\mathrm{TP}(\mathrm{g} / \mathrm{L})$ & $69.17 \pm 9.93$ & $60.76 \pm 13.45^{*}$ \\
$\mathrm{Alb}(\mathrm{g} / \mathrm{L})$ & $39.17 \pm 6.60$ & $32.76 \pm 8.21^{*}$ \\
$\mathrm{IgG}(\mathrm{g} / \mathrm{L})$ & $16.60 \pm 5.35$ & $14.47 \pm 7.02$ \\
$\mathrm{IgA}(\mathrm{g} / \mathrm{L})$ & $3.12 \pm 1.23$ & $3.04 \pm 1.20$ \\
$\mathrm{IgM}(\mathrm{g} / \mathrm{L})$ & $0.97 \pm 0.46$ & $0.98 \pm 0.61$ \\
$\mathrm{C}(\mathrm{g} / \mathrm{L})$ & $0.73 \pm 0.31$ & $0.66 \pm 0.31$ \\
$\mathrm{C} 4$ (g/L) & $0.15 \pm 0.09$ & $0.12 \pm 0.08^{*}$ \\
Anti-ds-DNA antibody (IU/ML) & $136.64 \pm 194.84$ & $357.06 \pm 450.05^{*}$ \\
SLEDAI & $8.36 \pm 0.81$ & $9.50 \pm 3.09$
\end{tabular}

WBC: white blood cell; RBC: red blood cell; HGB: hemoglobin; PLT: platelet; BUN: Clinical Disease Activity Index; Cr: creatine; TP: total protein; Alb: albumin; Ig: immunoglobulin; $\mathrm{C}_{3}$ : complement 3; $\mathrm{C}_{4}$ : complement 4; SLEDAI: SLE disease activity index.

Values are shown as mean $\pm S D$ unless otherwise noted

${ }^{*} p<0.05$ compared to Non-LN group.

\section{Comparison of serum creatinine based on the semi-quantitative determination of urinary protein and UPCR}

As shown in Figure 2A, patients with urinary protein $3+$ had higher serum creatinine levels than those with urinary protein - $(72.97 \pm 25.16$ vs. $54.83 \pm 11.09, \mathrm{P}=0.0001), \pm(72.97 \pm 25.16$ vs. $53.96 \pm 17.91$, $\mathrm{P}=0.0011)$, and $1+(72.97 \pm 25.16$ vs. $58.33 \pm 11.43$, $\mathrm{P}=0.0244)$. Figure $2 \mathrm{~B}$ shows that patients with positive urinary protein $(1+, 2+$ and $3+)$ had a higher serum creatinine level than those with urinary protein - and $\pm(64.72 \pm 19.40$ vs. $54.54 \pm 13.63, \mathrm{P}=0.0036)$. Meanwhile, the serum creatinine levels in patients with urinary protein $3+$ were significantly higher than in those with urinary protein $<3+(72.97 \pm 25.16$ vs. $57.32 \pm 14.37$, $\mathrm{P}=0.0002)$. We classified patients according to the UPCR, and with the increase of proteinuria, the serum creatinine of the patients showed a trend of gradual increase and the difference between the different groups was statistically significant $(\mathrm{P}=0.022)$. Patients with massive proteinuria showed significantly increased serum creatinine levels compared with other patients (Figure 2C).

\section{Comparison of creatinine clearance (Ccr) based on the semi-quantitative determination of urinary protein and UPCR}

As shown in Figure 3A, patients with urinary protein \pm had a significantly elevated Ccr, when compared to those with urinary protein $3+$ (130.6 \pm 44.15 vs. $110.5 \pm 33.50, \mathrm{P}=0.02)$. However, there was no significant difference in creatinine clearance among the other urinary protein groups. Similarly, as shown in Figure 3B, patients with urinary protein \pm had a significantly elevated Ccr, when compared to patients with urinary protein $(1+, 2+$ and $3+)$ (130.6 \pm 44.15 vs. $114.0 \pm 30.35, \mathrm{P}=0.0256)$. However, there were no statistically significant differences in creatinine clearance between urine protein - and + (115.7 \pm 29.32 vs. $117.7 \pm 34.36, \mathrm{P}=0.7210)$ between urine protein $(-$ and \pm ) and urine protein $(1+, 2+$ and $3+)$ $(120.7 \pm 35.40$ vs. $114.0 \pm 30.35, \mathrm{P}=0.1769)$, or between urine protein $<3+$ and $3+(118.5 \pm 32.63$ vs. $110.5 \pm 33.50$, $\mathrm{P}=0.2196)$. Similarly, we classified patients in the LN group according to UPCR, and patients with UPCR $<0.15 \mathrm{~g} / \mathrm{g}$ showed higher Ccr compared with patients with mild proteinuria $(0.15 \leq \mathrm{UPCR}<0.5 \mathrm{~g} / \mathrm{g})$ (132.44 \pm 21.02 vs. $111.82 \pm 34.90, \mathrm{P}=0.298)$, moderate proteinuria $(0.5 \leq \mathrm{UPCR}<3.5 \mathrm{~g} / \mathrm{g}) \quad(132.44 \pm 21.02$ vs. $115.69 \pm 37.80, \quad \mathrm{P}=0.382$ ), and massive proteinuria
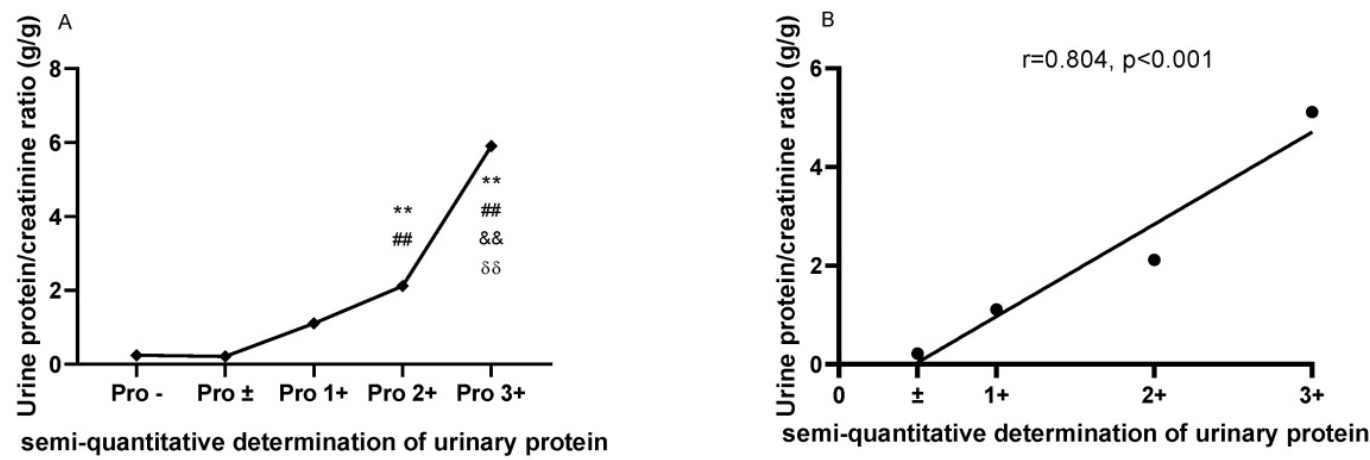

Figure 1. The comparisons and correlation between the urine protein/creatinine ratio (UPCR) and the semi-quantitative determination of urinary protein. A. The comparisons of the urine protein/creatinine ratio (UPCR) based on the semi-quantitative determination of urinary protein. B. The correlation between the urine protein/creatinine ratio (UPCR) and the semi-quantitative determination of urinary protein. The plots indicate the means of the urine protein/creatinine ratio. The statistical significance for the differences among multiple groups was determined using ANOVA. $* * P<0.01$ compared to Pro -; \#\# $<0.01$ compared to Pro \pm ; \&\&P<0.01 compared to Pro $1+;{ }^{80} \mathrm{P}<0.01$ compared to Pro $2+$ 
(UPCR $\geq 3.5 \mathrm{~g} / \mathrm{g}) \quad(132.44 \pm 21.02$ vs. $116.67 \pm 34.59$, $\mathrm{P}=0.626$ ) (Figure 3C). Patients with $\mathrm{UPCR}<0.15 \mathrm{~g} / \mathrm{g}$ showed significantly increased UPCR $\geq 0.15 \mathrm{~g} / \mathrm{g}$

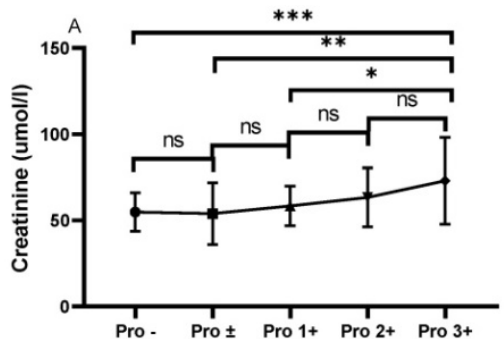

semi-quantitative determination of urinary protein

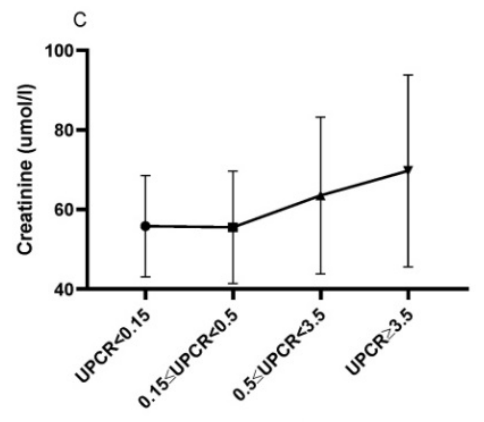

Urine protein/creatine ratio $(\mathrm{g} / \mathrm{g})$ compared to those with massive proteinuria (UPCR $\geq 3.5 \mathrm{~g} / \mathrm{g}) \quad(132.44 \pm 21.02$ vs. $115.14 \pm 35.89$, $\mathrm{P}=0.007$ ) (Figure 3D).

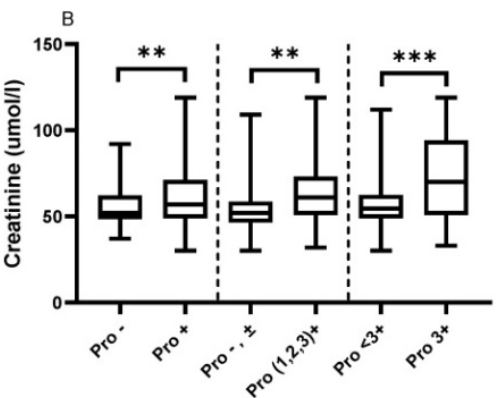

semi-quantitative determination of urinary protein

Figure 2. The comparison of serum creatinine based on the semi-quantitative determination of urinary protein. A. The Cr levels from Pro- to Pro $3+$. B. The comparison of $\mathrm{Cr}$ based on the different urinary protein groups. C. The Cr levels based on UPCR in the LN group. The statistical significance for the differences among multiple groups was determined using ANOVA. $* \mathrm{P}<0.05$, $* * \mathrm{P}<0.01$, $* * * \mathrm{P}<0.001$.

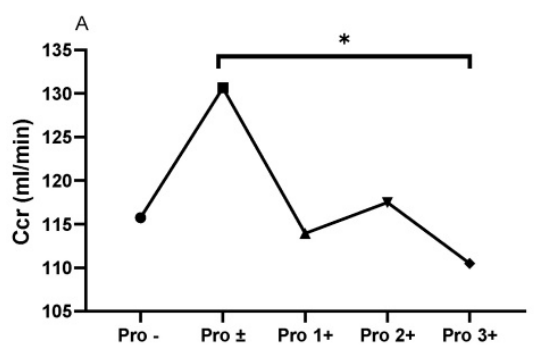

semi-quantitative determination of urinary protein

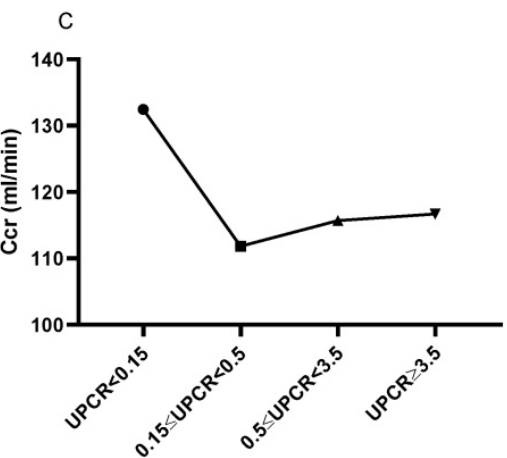

Urine protein/creatine ratio $(\mathrm{g} / \mathrm{g})$

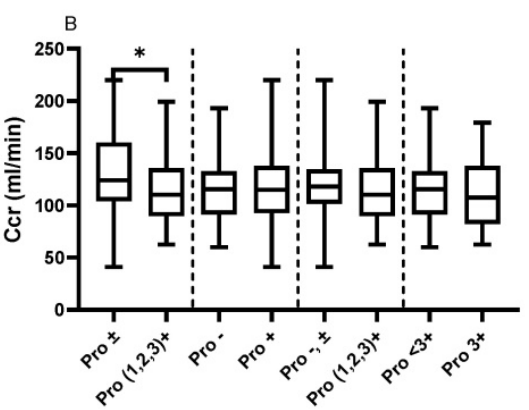

semi-quantitative determination of urinary protein

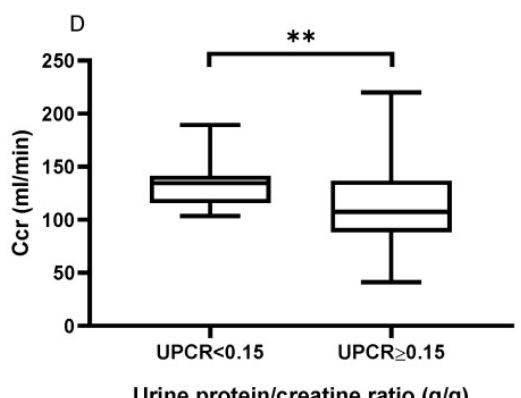

Urine protein/creatine ratio $(\mathrm{g} / \mathrm{g})$

Figure 3. The comparison of creatinine clearance (Ccr) based on the semi-quantitative determination of urinary protein and UPCR. A. The Ccr from Pro- to Pro 3+. The plots indicate the means of the $\mathrm{Ccr}$. B. The comparison of $\mathrm{Ccr}$ based on the different urinary protein groups. C. The Ccr trend based on UPCR in the LN group. D. The comparison of Ccr between UPCR $<0.15 \mathrm{~g} / \mathrm{g}$ and UPCR $\geq 0.15 \mathrm{~g} / \mathrm{g}$ in the $\mathrm{LN}$ group. The statistical significance for the differences among multiple groups was determined using ANOVA and the differences between two groups were determined using independent-samples t-test or Mann-Whitney $U$ test. *P<0.05, **P<0.01. 
The correlation between $\mathrm{Ccr}$ and the urine protein/creatinine ratio (UPCR), disease activity indexes and blood routine test in peripheral blood

There was no correlation between $\mathrm{Ccr}$ and the UPCR $(\mathrm{r}=-0.1383, \mathrm{P}=0.1272)$ in patients with positive urinary protein from Pro \pm to Pro $3+$ (Figure 4). Furthermore, there was no correlation between creatinine clearance and the other disease activity indexes, including $\operatorname{IgG}(\mathrm{r}=0.0179, \mathrm{P}=0.8235)$, IgM $(\mathrm{r}=-0.0232, \mathrm{P}=0.7727), \mathrm{C} 3 \quad(\mathrm{r}=0.0974, \mathrm{P}=0.2050), \mathrm{C} 4$ $(\mathrm{r}=0.0205, \quad \mathrm{P}=0.7897)$ and anti-ds-DNA antibody $(\mathrm{r}=-0.0741, \mathrm{P}=0.3472)$, except for $\operatorname{IgA} \quad(\mathrm{r}=-0.288$, $\mathrm{P}=0.002)$. Moreover, no correlations were observed between $\mathrm{Ccr}$ and HGB ( $\mathrm{r}=0.0143, \mathrm{P}=0.8494), \mathrm{RBC}$ $(\mathrm{r}=0.1005, \mathrm{P}=0.1805)$, PLT $(\mathrm{r}=0.1171, \mathrm{P}=0.1184)$ and $\mathrm{WBC}(\mathrm{r}=-0.0912, \mathrm{P}=0.2246)$.

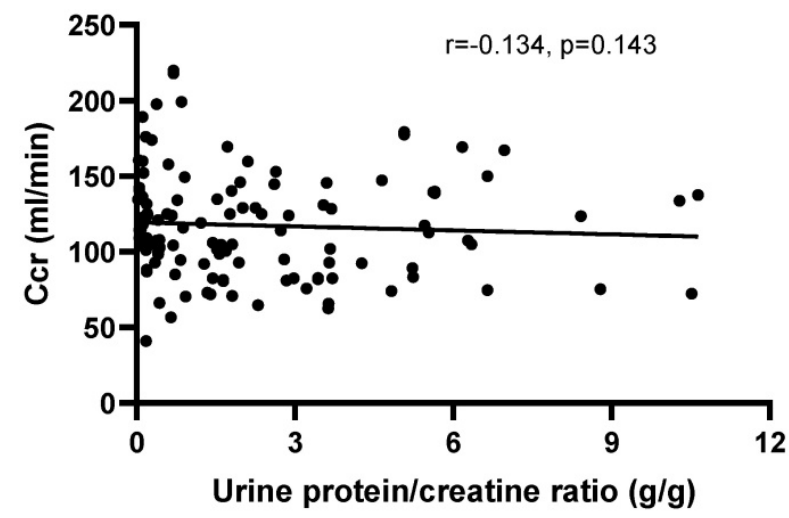

Figure 4. The correlation between creatinine clearance $(\mathrm{Ccr})$ and the urine protein/creatinine ratio (UPCR) in patients with positive urinary protein from Pro \pm to Pro 4+. The correlation was analyzed by Spearman's rank correlation test. $\mathrm{P}<0.05$ was considered statistically significant.

\section{The correlation between UPCR and RBC and HGB in peripheral blood}

As shown in Figure 5, with the increase of urine
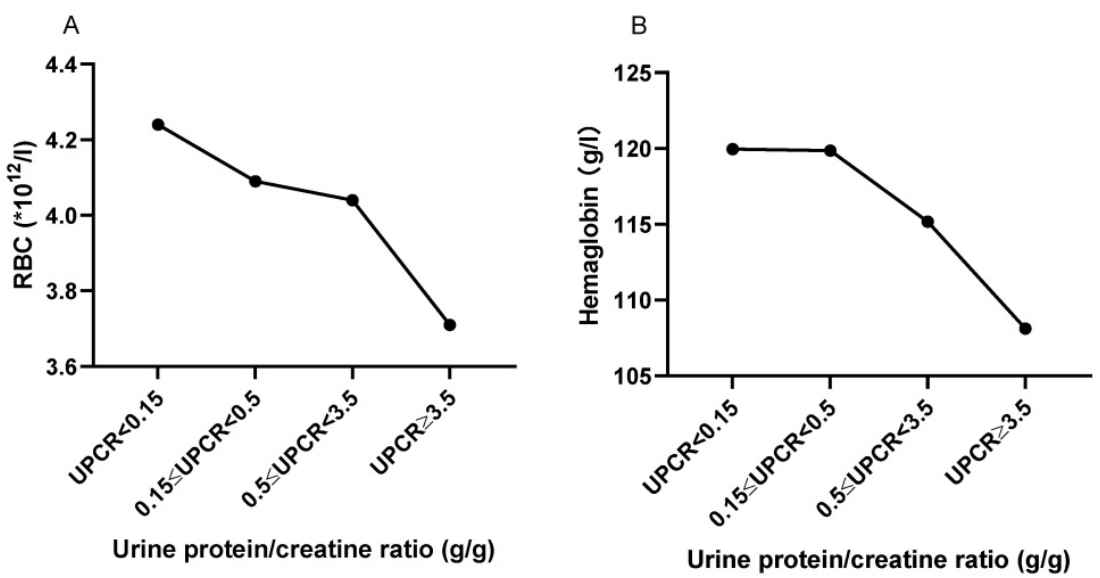

Figure 5. The trend of RBC and HGB based on UPCR. A. The RBC trend based on UPCR. B. The hemoglobin trend based on UPCR. The statistical significance for the differences among multiple groups was determined using ANOVA. protein, RBC and HGB in peripheral blood showed a trend of gradual decrease. Peripheral RBC of patients with massive proteinuria (UPCR $\geq 3.5 \mathrm{~g} / \mathrm{g}$ ) was significantly decreased compared with patients with normal range (UPCR $<0.15 \mathrm{~g} / \mathrm{g}) \quad(3.706 \pm 0.710$, vs. $4.238 \pm 0.762$, $\mathrm{P}=0.054)$. HGB also showed a similar trend to RBC. Also, UPCR was significantly negatively correlated with $\mathrm{RBC}(\mathrm{r}=-0.218, \mathrm{P}=0.016)$ and HGB $(\mathrm{r}=-0.180, \mathrm{P}=0.048)$.

\section{Discussion}

Lupus nephritis (LN) is one of the most common and serious manifestations of SLE [17]. Although new biomarkers such as monocyte chemoattractant protein-1 [18] have been used to assess LN disease activity, conventional assays such as serum creatinine, proteinuria, GFR, urine sediments, anti-dsDNA antibody, and the complement levels, despite their inadequate sensitivity and specificity for monitoring the disease activity and early relapse in LN [17, 19], are still the most commonly used clinical indicators of LN. In the present study, the investigators attempted to elucidate the role of urinary protein, the UPCR and Ccr, as indicators of disease activity or severity in LN patients with normal serum creatinine.

The proteinuria in patients with LN plays an important role in the diagnosis, disease activity monitoring, and prognosis of $\operatorname{LN}[20,21]$. The quantification of the protein content in the 24-hour urine collection sample $(24 \mathrm{hP})$ has been considered as the "gold standard". However, this test is very inconvenient for most patients and is sometimes incorrectly performed [22]. Recently, a strong correlation between the UPCR and $24 \mathrm{hP}$ in LN $[13,14]$ was observed in multiple studies [23, 24], and the UPCR was recommended by the American College of Rheumatology (ACR) [25] and the European League Against Rheumatism [26] for LN. In the present study, it was found that the UPCR closely correlated with the semi-quantitative determination of urine protein, which is consistent with previous studies [27, 28]. Therefore, in the clinical practice of rheumatology and nephrology, the diagnosis and disease activity monitoring of $\mathrm{LN}$ can be determined by combining the semi-quantitative urine protein test with the UPCR for LN patients who are not suitable for $24 \mathrm{hP}$.

Although serum creatinine cannot provide an adequate estimate of the glomerular filtration rate (GFR), serum creatinine remains by far the most widely used index for 
renal function in clinical practice and clinical trials [29, 30]. The present study revealed that the serum creatinine was significantly higher in $\mathrm{LN}$ patients than in Non-LN patients, as well as in patients with urinary protein $3+$ than in those with urinary Pro-, Pro \pm and Pro 1+. Meanwhile, the serum creatinine levels were significantly higher in patients with urinary protein $(1,2,3)+$ than in those with urinary protein negative and Pro \pm , and higher in patients with urinary protein $3+$ than in those with urinary protein $<3+$. These results suggest that although serum creatinine remains in the normal range in patients with urinary protein $3+$, signs of renal impairment have begun to appear. Therefore, for LN patients with large amounts of proteinuria, it is necessary not only to closely monitor the experimental indicators of renal injury but also to provide active treatment to prevent irreversible renal damage.

Ccr is a rapid and cost-effective method for the measurement of renal function [31]. Ccr approximates the calculation and overestimates the GFR by approximately $10 \%-20 \%$ [6]. Although creatinine clearance is not an accurate enough measure of GFR in clinical practice, it remains as the preferred clinical indicator of renal function for rheumatologists and nephrologists in LN outpatients due to its computability. Previous studies have focused on the value of $\mathrm{Ccr}$ in patients with abnormal serum creatinine [10], but the significance of Ccr in patients with normal serum creatinine, especially lupus nephritis, has not been reported. A study from Spain found that patients who developed contrast nephropathy had a lower creatinine clearance rate at admission even though their serum creatinine was in the normal range [32]. Another study reported that creatinine clearance increased in polytrauma patients with normal serum creatinine [33]. In the present study, patients with urinary protein \pm and UPCR $<0.15$ $\mathrm{g} / \mathrm{g}$ exhibited a significant Ccr increase when compared to the other urinary protein groups, especially the urinary Pro 3+ group, and this is similar to the renal presentation of diabetic nephropathy [14]. Alterations in renal function and structure were found even at the onset of diabetes mellitus, and in stages 2 and 3 of diabetic nephropathy, the glomerular filtration rate is elevated [14]. Therefore, the investigators inferred that the early stages of lupus nephritis would also present with an increase in GFR, and the present findings support this deduction.

Complement system [34], anti-dsDNA antibody $[35,36]$, and immunoglobulins [37] are involved in the pathogenesis of SLE. Among these, $\mathrm{C}_{3}, \mathrm{C}_{4}$ and the anti-dsDNA antibody are closely correlated to disease activity, which was a risk factor for organ damage and was significantly positively correlated with organ damage [38]. In the present study, there was no correlation between $\mathrm{Ccr}$ and the other disease activity indexes, including $\operatorname{IgG}, \operatorname{IgM}, \mathrm{C} 3, \mathrm{C} 4$ and the anti-ds-DNA antibody, except for IgA. Therefore, Ccr may not be a potential indicator of $\mathrm{LN}$ disease activity. Furthermore, the involvement of the hematologic system is a common clinical manifestation of SLE. The presence of hemolytic anemia in lupus patients is associated with a higher frequency of proteinuria and urinary cellular casts [39], and thrombocytopenia is highly comorbid with lupus nephritis [40]. In the present study, we found that RBC and HGB showed a gradual downward trend with the increase of urinary protein. This suggests that when the kidney of SLE patients is involved, it is often accompanied by the involvement of the hematologic system, which requires active therapeutic intervention.

\section{Conclusion}

In conclusion, although serum creatinine levels in SLE patients remain in the normal range, patients with urine protein have shown increased serum creatinine levels compared with patients with negative urine protein, suggesting that these patients have already presented early renal injury. At the same time, the patients with urine protein semi-quantitative \pm or UPCR $<0.15$ had higher Ccr than other patients, suggesting that the kidneys of these patients were in a state of hyperfunction. A high Ccr does not mean that the patient is in a very good kidney condition, but rather indicates that the patient is in an early stage of the disease, and early active intervention may help prevent permanent kidney damage.

\section{Limitations}

The present study is a single-center cross-sectional study. In the future, there is a need to expand the sample size and increase the number of research centers to further verify the conclusions of the present study. Since most patients with urinary protein $4+$ presented with elevated serum creatinine, they were not included in this study and will need to be further analyzed in the future.

\section{Acknowledgements}

Thank you to all the participants in this study.

\section{Funding}

This work was supported by the National Science Foundation for Young Scientist of China (81701605). 


\section{Competing Interests}

The authors have declared that no competing interest exists.

\section{References}

1. Mok CC, Tang SS, To CH, Petri M. Incidence and risk factors of thromboembolism in systemic lupus erythematosus: a comparison of three ethnic groups. Arthritis and rheumatism. 2005; 52: 2774-82.

2. Mok CC. Therapeutic options for resistant lupus nephritis. Semin Arthritis Rheum. 2006; 36: 71-81.

3. Rees F, Doherty M, Grainge MJ, Lanyon P, Davenport G, Zhang W. Mortality in systemic lupus erythematosus in the United Kingdom 1999-2012. Rheumatology (Oxford). 2016; 55: 854-60.

4. Hsieh YP, Wen $Y K$, Chen ML. The value of early renal biopsy in systemic lupus erythematosus patients presenting with renal involvement. Clin Nephrol. 2012; 77: 18-24.

5. Fulgeri C, Carpio JD, Ardiles L. Kidney injury in systemic lupus erythematosus: lack of correlation between clinical and histological data. Nefrologia. 2018; 38: 386-93.

6. Stevens LA, Coresh J, Greene T, Levey AS. Assessing kidney functionmeasured and estimated glomerular filtration rate. The New England journal of medicine. 2006; 354: 2473-83.

7. Levey AS, Bosch JP, Lewis JB, Greene T, Rogers N, Roth D. A more accurate method to estimate glomerular filtration rate from serum creatinine: a new prediction equation. Modification of Diet in Renal Disease Study Group. Annals of internal medicine 1999: 130: 461-70.

8. Schwartz GJ, Munoz A, Schneider MF, Mak RH, Kaskel F, Warady BA, et al. New equations to estimate GFR in children with CKD. J Am Soc Nephrol. 2009; 20: 629-37.

9. Sarnak MJ, Bloom R, Muntner P, Rahman M, Saland JM, Wilson PW, et al. KDOQI US commentary on the 2013 KDIGO Clinical Practice Guideline for Lipid Management in CKD. Am J Kidney Dis. 2015; 65: 354-66.

10. Leung YY, Lo KM, Tam LS, Szeto CC, Li EK, Kun EW. Estimation of glomerular filtration rate in patients with systemic lupus erythematosus. Lupus. 2006; 15: 276-81.

11. Cockcroft DW, Gault MH. Prediction of creatinine clearance from serum creatinine. Nephron. 1976; 16: 31-41

12. Kasitanon N, Fine DM, Haas M, Magder LS, Petri M. Estimating renal function in lupus nephritis: comparison of the Modification of Diet in Renal Disease and Cockcroft Gault equations. Lupus. 2007; 16: 887-95.

13. Martinez-Martinez MU, Borjas-Garcia JA, Magana-Aquino M, Cuevas-Orta E, Llamazares-Azuara L, Abud-Mendoza C. Renal function assessment in patients with systemic lupus erythematosus. Rheumatol Int. 2012; 32: 2293-9.

14. Mogensen CE, Christensen CK, Vittinghus E. The Stages in Diabetic Renal Disease: With Emphasis on the Stage of Incipient Diabetic Nephropathy. Diabetes. 1983; 32: 64-78.

15. Hochberg MC. Updating the American College of Rheumatology revised criteria for the classification of systemic lupus erythematosus. Arthritis and rheumatism. 1997; 40: 1725 .

16. Gladman DD, Ibanez D, Urowitz MB. Systemic lupus erythematosus disease activity index 2000. The Journal of rheumatology. 2002; 29: 288-91.

17. Soliman S, Mohan C. Lupus nephritis biomarkers. Clinical immunology. 2017; 185 : $10-20$

18. Živković V, Cvetković T, Mitić B, Stamenković B, Stojanović S, RadovanovićDinić B, et al. Monocyte chemoattractant protein-1 as a marker of systemic lupus erythematosus: an observational study. Rheumatology International. 2018; 38 : 1003-8

19. Mok CC. Biomarkers for lupus nephritis: a critical appraisal. Journal of biomedicine \& biotechnology. 2010; 2010: 638413

20. Balow JE. Clinical presentation and monitoring of lupus nephritis. Lupus. 2005; 14: 25-30.

21. Touma Z, Urowitz MB, Ibanez D, Gladman DD. Time to recovery from proteinuria in patients with lupus nephritis receiving standard treatment. The Journal of rheumatology. 2014; 41: 688-97.

22. Mitchell SC, Sheldon TA, Shaw AB. Quantification of proteinuria: a re-evaluation of the protein/creatinine ratio for elderly subjects. Age Ageing. 1993; 22: 443-9.

23. Choi IA, Park JK, Lee EY, Song YW, Lee EB. Random spot urine protein to creatinine ratio is a reliable measure of proteinuria in lupus nephritis in Koreans. Clinical and experimental rheumatology. 2013; 31: 584-8.

24. Chotayaporn T, Kasitanon N, Sukitawut W, Louthrenoo W. Comparison of proteinuria determination by urine dipstick, spot urine protein creatinine index, and urine protein 24 hours in lupus patients. J Clin Rheumatol. 2011; 17: 124-9.

25. Renal Disease Subcommittee of the American College of Rheumatology Ad Hoc Committee on Systemic Lupus Erythematosus Response C. The American College of Rheumatology response criteria for proliferative and membranous renal disease in systemic lupus erythematosus clinical trials. Arthritis and rheumatism. 2006; 54: 421-32.

26. Bertsias GK, Tektonidou M, Amoura Z, Aringer M, Bajema I, Berden JH, et al. Joint European League Against Rheumatism and European Renal
Association-European Dialysis and Transplant Association (EULAR/ERA-EDTA) recommendations for the management of adult and paediatric lupus nephritis. Ann Rheum Dis. 2012; 71: 1771-82.

27. Karkar A, Abdelrahman M. Protein-to-creatinine ratio: A valid estimate and alternative to 24 hour proteinuria. Saudi Journal of Kidney Diseases and Transplantation. 2010; 21: 949-50.

28. Wahbeh AM, Ewais MH, Elsharif ME. Comparison of 24-hour urinary protein and protein-to-creatinine ratio in the assessment of proteinuria. Saudi J Kidney Dis Transpl. 2009; 20: 443-7.

29. Levey AS, Perrone RD, Madias NE. Serum creatinine and renal function. Annu Rev Med. 1988; 39: 465-90.

30. Lacour B. [Creatinine and renal function]. Nephrologie. 1992; 13: 73-81.

31. Shahbaz H, Gupta M. Creatinine Clearance. StatPearls. Treasure Island (FL). 2019.

32. de Agustin JA, Carda R, Manzano Mdel C, Ruiz-Mateos B, Garcia-Rubira JC, Fernandez-Ortiz A, et al. [Creatinine clearance and contrast nephropathy in patients with normal creatinine levels]. Rev Esp Cardiol. 2007; 60: 772-6.

33. Minville V, Asehnoune K, Ruiz S, Breden A, Georges B, Seguin T, et al. Increased creatinine clearance in polytrauma patients with normal serum creatinine: a retrospective observational study. Crit Care. 2011; 15: R49.

34. Leffler J, Bengtsson AA, Blom AM. The complement system in systemic lupus erythematosus: an update. Ann Rheum Dis. 2014; 73: 1601-6.

35. Pan N, Amigues I, Lyman S, Duculan R, Aziz F, Crow MK, et al. A surge in anti-dsDNA titer predicts a severe lupus flare within six months. Lupus. 2014; 23: 293-8.

36. Floris A, Piga M, Cauli A, Mathieu A. Predictors of flares in Systemic Lupus Erythematosus: Preventive therapeutic intervention based on serial anti-dsDNA antibodies assessment. Analysis of a monocentric cohort and literature review. Autoimmun Rev. 2016; 15: 656-63.

37. Cass RM, Mongan ES, Jacox RF, Vaughan JH. Immunoglobulins G, A, and M in systemic lupus erythematosus. Relationship to serum complement titer, latex titer, antinuclear antibody, and manifestations of clinical disease. Annals of internal medicine. 1968; 69: 749-56.

38. Zivkovic V, Mitic B, Stamenkovic B, Stojanovic S, Dinic BR, Stojanovic M, et al. Analysis on the risk factors for organ damage in patients with systemic lupus erythematosus: a cross-sectional single-center experience. Sao Paulo Med J. 2019; 137: 155-61.

39. Jeffries M, Hamadeh $\mathrm{F}$, Aberle $\mathrm{T}$, Glenn $\mathrm{S}$, Kamen DL, Kelly JA, et al. Haemolytic anaemia in a multi-ethnic cohort of lupus patients: a clinical and serological perspective. Lupus. 2008; 17: 739-43.

40. Ktona E, Barbullushi M, Backa T, Idrizi A, Shpata V, Roshi E. Evaluation of thrombocytopenia in systemic lupus erythematosus and correlation with different organs damages. Mater Sociomed. 2014; 26: 122-4. 